\title{
Domestic and Family Violence and the Approach to Bail
}

\author{
Emily Ng and Heather Douglas
}

\begin{abstract}
A number of jurisdictions in Australia have introduced special provisions that either displace or reverse the presumption in favour of bail where domestic and family violence offences are alleged. This article examines the different approaches taken to bail in domestic violence cases across Australia in order to consider how to strike the best balance between protecting victims of family violence and upholding the rights of the accused. This article concludes that many of the legislative changes to bail presumptions are unjustified and that the safety of victims can be sufficiently protected by a focus on the basic assessment of whether the risk that the accused will harm the victim is unacceptable, and on a careful consideration and appropriate tailoring of the conditions of the bail grant.
\end{abstract}

\section{INTRODUCTION}

In several recent high-profile cases, men with histories of domestic and family violence have murdered a family member while on bail. In January 2013, Julie Grant was murdered by her ex-partner, Shannon Mahon, who was on bail for allegedly assaulting her and breaching an apprehended violence order. ${ }^{1}$ In February 2014, Greg Anderson murdered his son, Luke Batty, at Tyabb cricket ground. ${ }^{2}$ At the time of Luke's murder, Anderson was on bail on charges of assaulting and threatening to kill Luke's mother, Rosie Batty. ${ }^{3}$ These cases raise important questions about the role of bail in protecting victims of family violence. The criminal justice principles of personal liberty and the presumption of innocence are reflected in

1 Richard Noone, 'Accused Man Allegedly Killed Ex and Contravened an Apprehended Violence Order', The Daily Telegraph (online), 14 January $2013<$ <ttp://www.dailytelegraph.com.au/accused-man-allegedly-killed-exand-contravened-an-apprehended-violence-order/story-e 6 freuy 9 $1226553592761>$.

2 Adam Cooper, 'Luke Batty Inquest: No Urgency to Hold Dad Greg Anderson in Custody, Say Police', The Age (online), 1 December 2014 <www.theage.com.au/ victoria/luke-batty-inquest-no-urgency-to-hold-dad-greg-anderson-in-custodysay-police-20141201-11xns0.html>.

$3 \quad$ Ibid. Also note, in March 2015, Greg Thompson was arrested for the stabbing death of his ex-wife's boyfriend, Michael Moad. At the time of the stabbing Thompson was on bail for charges relating to intimidation of his ex-wife and her new partner and breaching an apprehended violence order. Dan Proudman, 'Accused Killer Was on Bail: Charged Twice Before Stabbing', Newcastle Herald (online), 2 March 2015 <www.theherald.com.au/story/2917611/ accused-killer-was-on-bail/>. 
the general presumption in favour of bail. ${ }^{4}$ However, these values are not absolute and must yield to public interests such as the protection of the community and particular individuals whose safety is threatened. ${ }^{5}$ For this reason, bail can serve an important function in preventing the accused from intimidating or harming witnesses and from committing further offences before trial. In a number of jurisdictions in Australia, bail laws have incorporated special provisions that either displace or reverse the presumption in favour of bail where domestic and family violence offences are alleged. ${ }^{6}$ The imposition of appropriate bail conditions may also help to minimise the risk of further harm to victims. ${ }^{7}$ For example, conditions that prohibit the accused from contacting, harassing, threatening or intimidating the victim may be imposed to reduce the risk of further family violence offending. ${ }^{8}$ Other common bail conditions in family violence cases may include exclusion conditions (where the accused is required to vacate the family home); prohibitions on contacting or approaching the victim; ${ }^{9}$ and perpetrator program conditions (where the accused is required to undergo treatment or counselling). ${ }^{10}$ The approach to bail in family violence cases varies significantly between Australian jurisdictions. In 2010, the Australian Law Reform Commission, in conjunction with the New South Wales Law Reform Commission (ALRC/NSWLRC Report), considered bail laws as part of their review of legal frameworks and how legal frameworks might better protect the safety of women and children. ${ }^{11}$ The ALRC/NSWLRC Report did not recommend the introduction of a presumption against bail in family violence cases. However, it concluded that judicial officers should be required to consider whether protective bail conditions should be imposed when bail is granted in family violence cases and further, if no protection order is in place, whether one should be made. ${ }^{12}$ Since the ALRC/NSWLRC Report was delivered there have

$4 \quad$ Bail Act 1980 (Qld) s 9; Bail Act 1985 (SA) s 10; Bail Act 1977 (Vic) s 4; Bail Act 1992 (ACT) ss 8-9; Bail Act 1982 (NT) s 8. In Tasmania, there is a common law presumption in favour of bail: see $R v$ Fisher [1964] Tas SR 318.

5 See, generally, New South Wales Law Reform Commission (NSWLRC), Bail, Report No 133 (2012) 65.

$6 \quad$ Bail Act 1985 (SA) s 10A; Bail Act 1977 (Vic) s 4(4)(ba); Bail Act 1982 (WA) Sch 1 Pt C cl 3B; Bail Act 1992 (ACT) s 9B(iv); Bail Act 1982 (NT) s 7A(1)(dd), (dh), where special provisions apply where the accused breached a protective condition while on bail.

7 See, for example, Law Reform Commission of Western Australia, Enhancing Family and Domestic Violence Laws, Report No 104 (2014) 134; Victorian Law Reform Commission (VLRC), Review of the Bail Act: Final Report (2007) 120.

8 See Bail Act 1977 (Vic) s 5(2A)(d); Bail Act 1992 (ACT) s 25(f)(i); Bail Act 1982 (NT) s 27A(1)(a)-(c).

$9 \quad$ See Bail Act 1985 (SA) s 11(2)(a)(ii); Bail Act 1994 (Tas) s 5(3A)(b); Bail Act 1977 (Vic) s 5(2A)(f); Bail Act 1992 (ACT) s 25(4)(f)(ii)-(v) in relation to police bail.

10 Bail Act 1985 (SA) s 21B; Bail Act 1982 (WA) Sch 1 Pt D cl 2(2b);.

11 Australian Law Reform Commission and New South Wales Law Reform Commission, Family Violence - A National Legal Response Final Report, Report No 114 (2010) (ALRC/NSWLRC Report).

Ibid [22], [420]. 
been several cases and reports that have again brought family violence and bail to public attention. ${ }^{13}$

Family violence is an entrenched and pervasive problem in Australia. In 2012, the Australian Bureau of Statistics found that around one in three women in Australia had experienced physical violence, almost one in five had experienced sexual violence, and approximately one in six had experienced violence by a partner. ${ }^{14}$ A 2013 Australian Institute of Criminology (AIC) report revealed that one woman is killed in Australia every week by a current or former partner..$^{15}$ In Queensland in 20132014 , there were 66,016 reported occurrences of domestic violence (up from 64,258 in 2012-2013) and 14,579 breaches of domestic violence court orders (up from 12,828 in 2012-2013), and in 2012-2013, 17 domestic violence related homicides (of the total 49 homicides). ${ }^{16}$ Similarly, the Victorian Sentencing Advisory Council reported that between 2004-05 and 2011-12, there was a 72.8 per cent increase in family violence incidents reported to Victorian police. ${ }^{17}$

Commonwealth, State and Territory governments are working with the community to implement the National Plan to Reduce Violence against Women and their Children 2010-2022. ${ }^{18}$ There is an ongoing debate about the role of criminal justice responses to family violence. Some academics and activists argue that involving the criminal justice system in domestic violence matters may reinforce the disadvantages already experienced by women. ${ }^{19}$ However, recent reviews of how approaches to family violence

13 NSWLRC, Bail, above n 5; Special Taskforce on Domestic and Family Violence in Queensland, Not Now, Not Ever: Putting an End to Domestic and Family Violence in Queensland (2015) 48 (Not Now, Not Ever Report); Law Reform Commission of Western Australia (WALRC), Enhancing Family and Domestic Violence Laws: Final Report, Project No 104 (2014). See also VLRC, Review of Family Violence Laws: Report (2006) 118-119.

14 Australian Bureau of Statistics, 4906.0-Personal Safety, Australia, 2012 (2013) <www.abs.gov.au/ausstats/abs@.nsf/mf/4906.0>.

15 Andy Chan and Jason Payne, 'Homicide in Australia: 2008-09 to 2009-10 National Homicide Monitoring Program Annual Report' (Monitoring Report No 21, Australian Institute of Criminology, 2013).

16 Not Now, Not Ever Report, above n 13, 47-48; Queensland Government, Premier's Special Taskforce on Domestic and Family Violence in Queensland (2014) <www. qld.gov.au/community/documents/getting-support-health-social-issue/taskforceterms-of-reference.pdf>.

17 Sentencing Advisory Council (Vic), Family Violence Intervention Orders and Safety Notices: Sentencing for Contravention (Monitoring Report, 2013).

18 Department of Social Services (Cth), The National Plan to Reduce Violence against Women and their Children 2010-2022 (2014) <www.dss.gov.au/ our-responsibilities/women/programs-services/reducing-violence/the-nationalplan-to-reduce-violence-against-women-and-their-children-2010-2022>.

19 See, generally, Donna Coker, 'Race, Poverty, and the Crime-Centred Response to Domestic Violence' (2004) 10(11) Violence Against Women 1331, 1332; Leigh Goodmark, A Troubled Marriage: Domestic Violence and the Legal System (New York University Press, 2012) 123; Heather Douglas, 'The Criminal Law's Response to Domestic Violence: What's Going On?' (2008) 30(3) Sydney Law Review 439. 
can be enhanced have emphasised that improvement in the criminal justice system is an important part of the response to family violence. ${ }^{20}$ This article proceeds on the basis that, in addition to broader community responses, existing criminal justice responses - of which bail is a core component - are an important aspect of the protection and safety of women and children.

Bail legislation varies throughout Australia and only in some jurisdictions does it define family violence offences for the purpose of any specialised approach to bail. While we consider this issue in our analysis of the particular provisions, our focus in this article is on non-fatal criminal offences perpetrated by the alleged perpetrator on a current or former intimate partner. This article examines bail practices in response to domestic violence cases across Australia in order to consider how to strike the best balance between protecting victims of family violence and upholding the rights of the accused. In a number of jurisdictions, bail presumptions have been changed in response to domestic violence so we focus significant attention on that issue. However, we also consider the use of appropriate bail conditions in the context of domestic violence. We conclude that many of the legislative changes to presumptions are unjustified and that safety of victims can be sufficiently protected by a focus on the basic assessment of whether the risk that the accused will harm the victim is unacceptable, and on a careful consideration and appropriate tailoring of the conditions of the bail grant.

\section{Bail Presumptions}

The presumption in favour of bail generally applies in New South Wales and Queensland for non-fatal offences that occur in the context of family violence. ${ }^{21}$ In these two jurisdictions bail will be refused where the prosecution shows on the balance of probabilities that the defendant, if released on bail would fail to appear, or while released on bail would commit an offence, endanger the safety or welfare of alleged victims or interfere with witnesses. ${ }^{22}$ The risk that the defendant would commit further incidents of domestic violence if placed on bail is a relevant consideration

20 ALRC/NSWLRC Report, above n 11, especially Ch 8; Not Now, Not Ever Report, above $\mathrm{n} 13,15$; VLRC, above n 13, 118-119; WALRC, above n 13, 127. Note in February 2015 the Royal Commission into Family Violence commenced in Victoria: Tracey Matters, Royal Commission Begins Community Consultations (10 April 2015) Royal Commission into Family Violence <www.rcfv.com.au/>. It was originally due to report in February 2016 with an extension granted until March 2016 and has a very broad ambit.

21 Bail Act 2013 (NSW) ss 17-20; Bail Act 1980 (Qld) s 9. Note pursuant to s 16(3) Bail Act 1980 (Qld) a reverse onus applies to bail in the context of some serious offences including offences with a maximum penalty of life imprisonment and offences against the Bail Act; similarly see the Bail Act 2013 (NSW) ss 16A and $16 \mathrm{~B}$.

22 Bail Act 2013 (NSW) s 17; Bail Act 1980 (Qld) s 16. 
in determining 'unacceptable risk' under the bail regimes in these two States. ${ }^{23}$

In domestic violence cases in the Australian Capital Territory, provisions that displace the presumption in favour of bail create what is referred to as a neutral presumption. ${ }^{24}$ In this context, courts have indicated that subject to prescribed criteria that must be taken into consideration:

[B]ail is at the court's discretion; that is, there is no requirement that bail be granted unless the court is satisfied that refusal is justified, but there is also no requirement that bail be refused unless the court is satisfied that the grant of bail is justified or perhaps that refusal of bail is not justified..$^{25}$

Although expressed in different ways in each jurisdiction, in Victoria, ${ }^{26}$ South Australia, ${ }^{27}$ Western Australia, ${ }^{28}$ Northern Territory ${ }^{29}$ and Tasmania, ${ }^{30}$ there is a presumption against bail in certain cases involving family violence. In some of these jurisdictions, courts have indicated that an application for bail should 'normally or ordinarily be refused'. ${ }^{31}$ The burden rests on the applicant to satisfy the court that bail should be granted. ${ }^{32}$ In Victoria the accused must 'show cause', ${ }^{33}$ in South Australia the accused must establish the existence of 'special circumstances' ${ }^{34}$ why bail should be granted, and in Western Australia the accused must satisfy the higher onus of 'exceptional reasons'. ${ }^{35}$

Presumptions against bail have been criticised for disproportionately affecting Aboriginal and unrepresented offenders, and for leading to the erosion of the presumption of innocence. ${ }^{36}$ Many commentators have

23 Note that in the case of certain serious indictable offences the defendant is placed in a show cause situation, and such offences may be committed in the context of domestic violence; see Bail Act 2013 (NSW) s 16B; Bail Act 1980 (Qld) s 16(3). See also Bail Act 2013 (NSW) s 18(1)(f) where the defendant's history of compliance with apprehended violence orders will also be considered.

24 Bail Act 1992 (ACT) s 9B.

25 Re Islam (2010) 175 ACTR 30, 80 [254] (Penfold J).

26 Bail Act 1977 (Vic) s 4(4)(ba).

27 Bail Act 1985 (SA) s 10A(ba).

28 Bail Act 1982 (WA) Sch 1 Pt C cl 3A.

29 Bail Act (NT) s 7A.

$30 \quad$ Family Violence Act 2004 (Tas) s 12.

31 See $R$ v Iskandar (2001) 120 A Crim R 302, 305 (Sperling J); $R$ v Seth Williams [2012] NTSC 47, [3] (Kelly J).

32 See $R$ v Iskandar (2001) 120 A Crim R 302, 305 (Sperling J); $R v$ Seth Williams [2012] NTSC 47, [3] (Kelly J).

33 Bail Act 1977 (Vic) s 4(4)(ba). The relevant Northern Territory provision states, 'Bail must not be granted to a person accused of an offence to which this section applies unless the person satisfies an authorised member or court that bail should be granted'. Bail Act (NT) s 7A(2).

34 Bail Act 1985 (SA) s 10A.

35 See Taylor v Western Australia [2014] WASC 292.

36 David Pheeney, “Do You Reckon I'm Gunna Get Bail?”: The Impact and Consequences of New South Wales Bail Laws on Aboriginal Juveniles' (2012) 7(30) Indigenous Law Bulletin 3. Note also bail legislation in some Australian jurisdictions includes special provisions that require courts to consider Indigenous 
observed that the proliferation of presumptions against bail generally has led to a steady increase in the number of bail refusals and the number of people being held on remand. ${ }^{37}$ The use of remand to avert risk and its contribution to the rapid growth in prison populations has become a significant socio-legal issue. ${ }^{38}$ Of concern is that the expanding numbers of prisoners may divert resources away from rehabilitation programs to prison places; the latter has been found to be less cost-effective in reducing reoffending. ${ }^{39}$ Researchers have examined the effect of bail presumptions under the now repealed Bail Act 1978 (NSW) on the likelihood of bail refusal and found that the risk of bail refusal was lower in 'presumption in favour' cases ( 2 per cent) compared to 'neutral presumption' ( 5 per cent), 'presumption against' (3 per cent) and 'exceptional circumstances' cases (5 per cent). ${ }^{40}$ However, the authors observed that in none of these cases could it fairly be said that bail was 'normally' or 'ordinarily' refused. ${ }^{41}$ Below, we consider the merits and limitations of legislative and judicial approaches to bail in four Australian jurisdictions that have introduced a specialised approach to bail in family violence cases: Victoria, Australian Capital Territory, Western Australia and Tasmania. ${ }^{42}$

offenders' cultural issues and obligations, see, for examples, Bail Act 1977 (Vic) s 3A; Crimes Act 1914 (Cth) s 15AB(3A)(a).

37 See Don Weatherburn, Wai-Yin Wan and Simon Corben, 'Why is the NSW Prison Population Growing?' (Issue Paper No 95, NSW Bureau of Crime Statistics and Research, 2014); Tracey Booth and Lesley Townsley, 'The Process is the Punishment: The Case of Bail in New South Wales' (2009) 21(1) Current Issues in Criminal Justice 41; Anthea Hucklesby and Rick Sarre, 'Bail in Australia, the United Kingdom and Canada: Introduction' (2009) 21(1) Current Issues in Criminal Justice 1; Cheryl Marie Webster, Anthony N Doob and Nicole M Myers, 'The Parable of Mrs Baker: Understanding Pre-trial Detention in Canada' (2009) 21(1) Current Issues in Criminal Justice 79; Myles F McLellan, 'Bail and the Diminishing Presumption of Innocence' (2010) 15 Canadian Criminal Law Review 57.

38 Weatherburn, Wan and Corben, above n 37, 1; see, generally, Chris Cunneen et al, Penal Culture and Hyperincarceration (Ashgate, 2013).

39 Francis Cullen, Cheryl Jonson and Daniel Nagin, 'Prisons Do Not Reduce Recidivism' (2011) 91(3) The Prison Journal 48; see generally Smart Justice, More Prisons Are Not the Answer to Reducing Crime (22 September 2014) <www. smartjustice.org.au/cb_pages/more_prisons_are_not_the_answer_to_reducing_crime.php>.

40 Lucy Snowball, Lenny Roth and Don Weatherburn, 'Bail Presumptions and Risk of Bail Refusal: An Analysis of the NSW Bail Act' (Issue Paper No 49, NSW Bureau of Crime Statistics and Research, 2010).

41 'Neutral presumption' cases were more likely to result in bail refusal than 'presumption against' cases, potentially because 'neutral presumption' cases (which involved serious sexual offences, cases of serious violence, and domestic violence cases) involved risks to particular people or the community, whereas 'presumption against' cases were mostly repeat property offences which posed a lesser risk to the community by release.

42 We have not examined the Northern Territory in detail as its legislation has recently been amended and there has been little discussion to date of its operation in the literature or case law. We have not examined South Australia as its application is extremely limited: pursuant to Bail Act 1985 (SA) s 10A(ba) the accused must show cause in circumstances where s/he is taken into custody in 


\section{A Show Cause - Victoria}

In the family violence context, Victoria adopts a 'show cause' approach to the presumption against bail. Under the Bail Act 1977 (Vic) (the Victorian Act), there is a presumption against bail for stalking ${ }^{43}$ and contravention of a family violence intervention order by the use or threatened use of violence. ${ }^{44}$ In both cases, the presumption applies where the accused has:

(a) in the previous 10 years been convicted or found guilty of an offence involving the use or threat of violence; or

(b) on a separate occasion used or threatened violence against the same person, regardless of whether the accused has been convicted, found guilty of, or charged with, an offence. ${ }^{45}$

In these circumstances the court must refuse bail unless the accused shows cause why their detention is not justified. ${ }^{46}$ The considerations which may be relevant to showing cause are not specified in the Victorian Act. Each case must be assessed according to its own facts and circumstances. A particular factor or, more commonly, a combination of factors may result in an accused being able to show cause. ${ }^{47}$

Similar to other jurisdictions, the Victorian Act also provides that the court must refuse bail where it is satisfied that, if released on bail, there is an unacceptable risk that the accused would not return to court, commit an offence whilst on bail, endanger the safety or welfare of members of the public, or interfere with witnesses. ${ }^{48}$ In deciding these matters, the court may consider:

(a) the nature and seriousness of the offence;

(b) the character, antecedents, associations, home environment and background of the accused;

(c) the history of any previous grants of bail to the accused person;

(d) the strength of the evidence against the accused person;

(e) the attitude, if expressed to the court, of the alleged victim of the offence to the grant of bail; and

(f) any conditions that may be imposed to address the circumstances which may constitute an unacceptable risk. ${ }^{49}$

The Victorian Family Violence Bench Book acknowledges that there are divergent views on whether the Victorian Act creates a single stage test

relation to an offence of breaching a protection order where the alleged offence involved physical violence or a threat of physical violence. See $R v$ Doyle [2014] SASC 199 for a discussion of the operation of bail in family violence cases in domestic violence.

43 Bail Act 1977 (Vic) s 4(4)(b). Stalking is commonly associated with family violence, see AW Burgess et al, 'Stalking Behaviours within Domestic Violence' (1997) 12 Journal of Family Violence 389.

Bail Act 1977 (Vic) s 4(4)(ba).

45 Bail Act 1977 (Vic) s 4(4)(b)-(ba).

46 Bail Act 1977 (Vic) s 4(4).

47 DPP v Harika [2001] VSC 237 at [47] (Gillard J).

48 Bail Act 1977 (Vic) s 4(2)(d).

49 Bail Act 1977 (Vic) s 4(3). 
or a two-stage test when the presumption against bail applies. ${ }^{50}$ Recently the case of Robinson $v$ The Queen ${ }^{51}$ considered this issue. In this case the court seems to suggest that the question of whether the relevant test has one or two steps is not particularly important as either way the judge will be bound to decide whether there is an unacceptable risk of a relevant matter. The court observed that '[i]n a case where the prosecution asserts that one of the contemplated risks exist, and the accused is obliged to show cause why his/her detention in custody is not justified, there will be a single inquiry into risk'. ${ }^{52}$

The case of Romas $v$ DPP provides a good example of how the Victorian courts approach bail in family violence matters. ${ }^{53}$ In this case Coghlan $\mathrm{J}$ found that the fact that the accused would be detained for 19 out of 20 months before trial, together with the fact that he had accommodation and employment available to him, was enough to show cause why bail should be granted. ${ }^{54}$ Nonetheless, bail was refused because there was an unacceptable risk of the accused interfering with witnesses and reoffending on bail because his offending involved allegations of 50 breaches of intervention orders. ${ }^{55}$

In Victoria, the requirement for the defendant to show cause is limited to stalking and contravention of a protection order, but being charged with these types of offences will not be sufficient to trigger the show cause requirement. There must also be some history of previous violence or previous threats of violence towards the victim of the current offence. It is notable that these previous instances do not need to have been charged or successfully prosecuted. Thus, it appears possible that the presumption could be triggered by allegations of previous threats without more. However, the show cause requirement operates in a limited context and the test is ultimately whether the defendant presents an unacceptable risk of reoffending or interfering with witnesses.

\section{B Neutral Presumption - Australian Capital Territory}

The Australian Capital Territory has legislated different approaches for police and court bail in relation to domestic violence offences. For police bail, a police officer must not grant bail for a domestic violence offence unless satisfied that the accused poses no danger to a victim while released on bail. ${ }^{56}$ This is an extremely high threshold and it is difficult to imagine a situation where a court could be confident that an accused posed

50 Judicial College of Victoria, Family Violence Bench Book (18 January 2016) $<$ www.judicialcollege.vic.edu.au/eManuals/FVBBWeb/index.htm\#34488.htm>.

51 [2015] VSCA 161.

52 Ibid, [42] (Maxwell P and Redlich JA).

53 [2014] VSC 499.

54 Ibid.

55 Similarly, see Held $v$ The Queen [2012] VSC 648.

56 Bail Act $1992(\mathrm{ACT}) \mathrm{s}$ 9F. 
no danger. ${ }^{57}$ The Bail Act 1992 (ACT) defines an offence as a domestic violence offence if the conduct making up the offence is domestic violence under the Domestic Violence and Protection Orders Act 2008 (ACT). ${ }^{58}$ Under that Act, the use or threat of violence against current or former domestic partners, children of domestic partners, and intimate partners amounts to domestic violence. ${ }^{59}$ This approach was evaluated in 2012 and it was found that it enhanced victim safety. ${ }^{60}$

For court bail in the Australian Capital Territory, there is a neutral presumption for the offences of threat to kill, threat to inflict grievous bodily harm, stalking, and contravention of a protection order, where the accused has in the previous 10 years been found guilty of an offence involving violence or threat of violence. ${ }^{61}$ However, the protection offered by the provision is limited in family violence cases because the general presumption in favour of bail is retained where the accused is charged with other violent offences that may be common in the context of family violence, including assault and assault occasioning actual bodily harm.

In Re Breen, Refshauge J said that in cases where there was no statutory presumption in favour or against bail, the accused bears an onus of putting forward material sufficient to satisfy the court that bail should be granted to him and the court must be satisfied of any relevant matter on the balance of probabilities. ${ }^{62}$ His Honour considered s 18 of the Human Rights Act 2004 (ACT) which prescribes a right to liberty and a right to persons awaiting trial not to be detained as a general rule. Section 30 of the Human Rights Act requires Australian Capital Territory laws to be interpreted in a way that is compatible with human rights so far as is possible. In view of these provisions, his Honour said that a strict application of the onus on the applicant did not seem appropriate. ${ }^{63}$ However, Refshauge J emphasised that the information available to the prosecution and the attitude of the prosecution to bail should also be considered by the court. ${ }^{64}$

57 As Derrington J observed in Williamson v DPP (Qld) [1999] QCA 356, [21]: ‘No grant of bail is risk free'.

58 Bail Act 1992 (ACT) Sch 1.

59 Domestic Violence and Protection Orders Act 2008 (ACT) ss 13, 15.

60 Tracy Cussen and Mathew Lyneham, 'ACT Family Intervention Program Review' (Technical and Background Paper No 52, Australian Institute of Criminology, 2012). See also Robyn Holder and Nicole Mayo, 'What Do Women Want in Prosecuting Family Violence in the ACT' (2003) 15(1) Current Issues in Criminal Justice 5.

61 Bail Act 1992 (ACT) s 9B.

62 (2009) 172 ACTR 2.

63 Ibid, [51]. But since Re Breen was decided see Momcilovic v The Queen (2011) 245 CLR 1, where the High Court considered a similar provision of the Charter of Human Rights and Responsibilities Act 2006 (Vic) and found that the requirement that 'statutory provisions must be interpreted in a way which is compatible with human rights' referred to no more than the ordinary judicial task of statutory interpretation; that is, consideration of a provision's terms, context and purpose.

64 Re Breen (2009) 172 ACTR 21, [52], quoting Douglas Brown, 'Bail: An Examination' (1971) 45 Australian Law Journal 193, 198. 
Unlike the presumption against bail in Victoria, the neutral presumption for court bail in the Australian Capital Territory operates only where the accused has already been found guilty of an offence involving violence or threat of violence. For example, in $R v$ Eiginson the neutral presumption did not apply because, although the accused had a history of family violence, he did not have criminal convictions for violent offending. ${ }^{65}$ Although the Australian Capital Territory provision covers a wider range of violent behaviours than the Victorian provision (which is limited to stalking and contravention of a protection order), the Australian Capital Territory provision is ultimately narrower in its application than Victoria because of the requirement of a finding of guilt in relation to past offences of violence and threats.

\section{Exceptional Reasons - Western Australia}

Curiously in Western Australia, under s 16A(3) of the Bail Act 1982 (WA), the police do not have jurisdiction to grant bail in respect of breaches of protection orders in urban areas. In urban areas the accused must be brought before a magistrate for consideration of bail. The practical reason for this approach is that the accused can be brought before a court without delay in urban areas whereas in regional and remote areas the court may not be sitting and there may be significant delay if police are excluded from bail decisions. ${ }^{66}$ In 2013, the Law Reform Commission of Western Australia (WALRC) proposed that s 16A(3) be repealed. ${ }^{67}$ The WALRC found that an unintended consequence of $\mathrm{s} 16 \mathrm{~A}(3)$ is to encourage police to avoid the issue of bail by using the summons process for breach of a protection order instead of arrest. ${ }^{68}$ Ultimately, and likely an unintended consequence of this approach is that a person may not be required to abide by any conditions associated with bail (such as staying away from the alleged victim). ${ }^{69}$ This may in effect place victims at increased risk.

For bail generally in Western Australia, there is a presumption against bail where the accused commits a serious offence (these include breach of a protection order, assault occasioning bodily harm and stalking) while on bail for another serious offence..$^{70}$ The accused is required to show exceptional reasons why he should not be kept in custody. In cases of breach of a protection order, before making a decision as to whether

65 [2014] ACTSC 234. See also $R v$ Elphick [2014] ACTSC 372 at [9]-[12], where the neutral presumption did not apply. Although Mr Elphick had a history of family violence, the only conviction on his record at the time was for being an accessory after the fact, which was not considered an offence of actual or threatened violence.

66 WALRC, above n 13, 135-136.

67 Ibid (Recommendation 48).

68 Ibid, 135.

69 The importance of appropriate bail conditions in domestic violence cases is discussed further below, but see Bail Act 1982 (WA) s 17.

70 Bail Act 1982 (WA) Sch 1 Pt C cll 3A, 3B. The full list of serious offences is set out in Sch 2. 
there are exceptional reasons, the court is to make enquiry as to whether there has been any other proven breach of the protective condition, any other alleged breach of that condition or any other alleged breach of any other such condition that has been the subject of prosecution. ${ }^{71}$ The court must give any person for whose protection a protective condition has been imposed a reasonable opportunity to give evidence by affidavit on the matters relating to that condition. ${ }^{72}$ For example, in Taylor $v$ Western Australia, the court took into consideration the victim's affidavit, in which she explained that her relationship with the accused was marked by domestic violence and highlighted her fears that the applicant would find her and kill her if released. ${ }^{73}$ The Western Australian Act also sets out specific factors that must be taken into account in considering whether bail should be granted in a case involving an alleged breach of a protective condition. ${ }^{74}$ However, 'exceptional reasons' is an extremely difficult standard to satisfy. In Gilmour $v$ Western Australia, Simmonds J was unable to discern that any exceptional reasons had been made out by the applicant. ${ }^{75}$ While there were circumstances that pointed towards the grant of bail, namely, delay before trial, hardship to the applicant and his relatively modest criminal history, the overall character of these circumstances was not sufficient to establish exceptional reasons. ${ }^{76}$

However, there are many family violence situations where this presumption does not apply. For example, in Rock $v$ Western Australia, the applicant was charged with aggravated armed burglary with intent, and unlawful wounding with intent to maim, disfigure, disable or do some grievous bodily harm in September 2012. ${ }^{77}$ It was alleged that the applicant banged on the door of the house where his ex-partner lived, demanding to be let in. He smashed the side sliding glass door, gained entry and started swinging a tomahawk at her, hitting her with the blade, which cut her head and fractured her arm. During the assault, the applicant kicked and punched the victim's head and body causing cuts and bruises. The applicant had previously assaulted the victim, when she was his partner, in 2008. The applicant had pleaded guilty to that offence, and was sentenced to a 12-month supervisory order, which included attendance at an anger management course. Nonetheless, the presumption against bail did not apply to the 2012 offences because the applicant was not on bail at the time. While Simmonds J found that the 2008 incident was of a domestic violence character, her Honour observed that it is often a matter of difficulty to determine how best to characterise an incident. ${ }^{78}$ The case

$71 \quad$ Bail Act 1982 (WA) Sch $1 \mathrm{Pt} \mathrm{C} \mathrm{cl} \mathrm{3B(2).}$

72 Bail Act 1982 (WA) Sch $1 \mathrm{Pt} \mathrm{C} \mathrm{cl} \mathrm{3B(3).}$

73 [2014] WASC 292, [23].

74 Bail Act 1982 (WA) Sch 1 Pt C cl 3B(4).

75 [2005] WASC 243.

76 Gilmour $v$ Western Australia [2005] WASC 243 at [69]. See also the difficulties faced by the applicant in Taylor $v$ Western Australia [2014] WASC 292.

77 [2013] WASC 295.

78 Ibid. 
not only reveals a potential concern with the inconsistent application of the presumption against bail, but also the need for the criminal law to define a 'family violence offence' and prescribe a procedure for recording such offences on a person's criminal record. ${ }^{79}$

\section{Not Likely to Adversely Affect Victim's Safety - Tasmania}

Tasmania has introduced yet another alternative approach to the presumption in bail cases involving domestic violence. In 2003, the Tasmanian Attorney-General, Judy Jackson, supported the introduction of a domestic violence framework called Safe at Home. ${ }^{80}$ The new policy approach aimed to enhance the criminal justice system's response to family violence. ${ }^{81}$ As part of those reforms the new Family Violence Act 2004 (Tas) was introduced; s 12 provides that a person charged with a 'family violence offence' is not to be granted bail unless a judge, court or police officer is satisfied that their release would not be likely to adversely affect the safety, wellbeing and interests of an affected person or child. ${ }^{82}$ The Family Violence Act 2004 (Tas) defines 'family violence offence' as any offence the commission of which constitutes family violence. ${ }^{83}$ Pursuant to this legislation, 'family violence' means any of the following types of conduct committed against that person's spouse or partner:

(a) assault, including sexual assault;

(b) threats, coercion, intimidation or verbal abuse;

(c) abduction;

(d) stalking;

(e) attempting or threatening to commit conduct referred to above. ${ }^{84}$

It also includes economic abuse, emotional abuse or intimidation, and contravening a family violence order (FVO) or an interim FVO.$^{85}$ Notably, in $S v$ White, Blow $\mathrm{J}$ observed that the definition of a 'family violence offence' does not extend to violence inflicted upon a child living in the household. ${ }^{86}$ This means the presumption against bail does not apply to violence against children. However, if the perpetrator is charged with assaulting their spouse or partner, then the safety, wellbeing and interests of the child become relevant in the decision to grant bail, pursuant to the wording of $\mathrm{s} 12(1) .{ }^{87}$

79 The recommendation that criminal records should clearly identify domestic violence-related offences has been made by a number of Law Reform Commission reports. See Not Now, Not Ever Report, above n 13, 305; ALRC/NSWLRC Report, above n 11,542 .

80 Department of Justice and Industrial Relations, Safe at Home: A Criminal Justice Framework for Responding to Family Violence in Tasmania (2003) 25.

81 Ibid, 4.

82 Family Violence Act 2004 (Tas) s 12.

83 Family Violence Act 2004 (Tas) s 4.

84 Family Violence Act 2004 (Tas) s 7(a).

85 Family Violence Act 2004 (Tas) s 7(b).

86 [2005] TASSC 27 (21 April 2005) at [13].

87 Ibid. 
The policy intent of the legislation was to address intimate partner violence, while at the same time increasing the safety of children. ${ }^{88}$ In the second reading speech, Judy Jackson said:

The aim of the Family Violence Bill is to give priority to the safety, psychological wellbeing and interests of people affected by family violence. We've been perfectly up-front about that; it is in the objects of the clause. There is no point in the legislation having those aims but then letting violent individuals back out on the streets when we cannot be confident that their potential victims can be safe..$^{89}$

Section 12 has attracted criticism from several Supreme Court justices. ${ }^{90}$ In Olsen $v$ Tasmania, the accused was charged with one count of aggravated assault, which consisted of a threatening gesture to his former partner with a replica pistol. ${ }^{91}$ The prosecution opposed bail because the accused was unable to produce a surety. Underwood CJ regarded the assault as not a serious one and noted that the accused would be in custody for some time before his case was heard. His Honour revealed that were he free of the restraints imposed by the Family Violence Act 2004 (Tas), he would have granted bail. ${ }^{92}$ His Honour said the difficulty was that under s 12 the onus was on the accused to satisfy the court that his release would not be likely to adversely affect the safety, wellbeing and interests of the complainant. In refusing bail, his Honour emphasised:

Without knowing where she is living and without a surety to monitor the applicant's behaviour, I regret to say I cannot be so satisfied, and I must reject the application for bail. In doing so, I want to say very strongly that this man needs legal assistance and he needs it urgently, otherwise he is likely to stay where he is for a considerable period of time because of the provisions of the Family Law Act, s $12 .{ }^{93}$

Chief Justice Underwood reaffirmed his view in his submission to the Review of the Family Violence Act 2004 (Tas):

It is one thing to take into account the safety, wellbeing and interests of an affected person or an affected child, it is quite another to refuse liberty unless the defendant discharges the onus of proof cast on him (or her - but it is invariably him) by s $12(1) .{ }^{94}$

In effect, the Tasmanian provision is more onerous on the accused than the provisions in Victoria and the Australian Capital Territory. The provision

88 Urbis, Review of the Family Violence Act 2004 (Tas) (March 2008) 13 (prepared for Department of Justice, Tasmania).

89 Tasmania, Parliamentary Debates, House of Assembly, 18 November 2004, 119-194 (Judith Jackson, Attorney-General and Minister for Justice and Industrial Relations).

90 See Re S [2005] TASSC 89 (19 September 2005) (Slicer J); Olsen v Tasmania [2005] TASSC 40 (13 May 2005) (Underwood CJ).

91 [2005] TASSC 40 (13 May 2005).

92 Ibid, [3].

93 Ibid, [10].

94 Urbis, above n 88, 15. 
requires that the accused satisfy the court that he does not represent an unacceptable risk to the victim and her children. ${ }^{95}$

Magistrates have acknowledged that they are more reluctant to grant bail under the Family Violence Act 2004 (Tas). ${ }^{96}$ The Review of the Family Violence Act 2004 (Tas) found there were mixed views about the appropriateness of the presumption against bail with some seeing it as 'too high a price' to pay before allegations had been tested and proved and others viewing it as 'highly appropriate'. ${ }^{97}$ There was, however, a view expressed from a range of stakeholders that magistrates seemed to be granting bail more frequently after the first year of operation of the legislation. Data is not available to determine whether this is in fact the case. ${ }^{98}$

\section{E Overview - Bail Presumptions}

This survey of the various legislative presumptions about bail in family violence cases demonstrates there is a patchwork of different approaches throughout Australia. These different responses have developed in an ad hoc way, sometimes in response to the recommendations of law reform inquiries. At present, Tasmania and the Australian Capital Territory are the only jurisdictions that define 'family violence offence' and 'domestic violence offence', respectively, for the purposes of bail. ${ }^{99}$ In all other jurisdictions in Australia, family violence offences are not specifically defined in connection with bail decisions. In the Australian Capital Territory, Northern Territory, Victoria and South Australia, in bail applications where the accused has a history of violence, the offence of breach of a protection order attracts a specific approach, either a 'neutral presumption'100 or 'presumption against bail'; ${ }^{101}$ however, violent offences committed in the context of family violence are not given any special status.

In its submission to the ALRC/NSWLRC, the North Australian Aboriginal Justice Agency criticised the Tasmanian and Australian Capital Territory approach, observing that more minor family violence matters, such as contacting the protected person by email or text message,

95 This approach resembles the approach criticised and ultimately rejected by Justice Bell in Victoria, see Woods v DPP (Vic) [2014] VSC 1 (17 January 2014).

96 Urbis above $\mathrm{n} 88,16$.

97 Ibid, 4.

98 Ibid, 6.

99 In the Australian Capital Territory, the definition of 'domestic violence offence' is contained within the dictionary of the Bail Act 1992 (ACT) and relates to police bail only s $9 \mathrm{~F}$.

100 See Bail Act 1992 (ACT) s 9B, where, although there is a presumption against bail for the offences of threat to kill, threat to inflict grievous bodily harm, stalking, and contravention of a protection order, the general presumption in favour of bail is retained for violent offences that are common to family violence contexts, including assault occasioning actual bodily harm.

101 Bail Act 1985 (SA) s 10A; Bail Act 1977 (Vic) s 4(4)(ba); Bail Act (NT) s 7A(1)(dh). 
can be subject to presumptions against bail. ${ }^{102}$ The $A L R C / N S W L R C$ Report suggested:

A presumption against bail ... seems inappropriate for some crimes in a family violence context. Without dismissing the seriousness of any type of breach of a protection order, it would seem that a breach of a contact condition of a protection order that does not involve any family violence, particularly where the protected person invited the contact uncoerced, might not justify a presumption against bail. ${ }^{103}$

The Victorian and South Australian legislation has attempted to address this concern by creating a presumption against bail only where the perpetrator breaches a protection order though an act or threat of physical violence. ${ }^{104}$ In their submission to the ALRC/NSWLRC inquiry, the Magistrates' Court and Children's Court of Victoria submitted that bail legislation may provide better protection for victims if provisions of this nature were not limited to contraventions of intervention orders and included a set of principles to be applied in deciding all bail applications arising from family violence offences. ${ }^{105}$

Notably, the special approach taken to bail in Victoria, South Australia and the Northern Territory only applies where family violence victims already have a protection order and there is a breach of that order. The rationale for this approach, according to the courts, is that breaches of protection orders indicate the accused's inability to comply with constraints imposed by lawful authority, which gives the court no confidence that the imposition of bail conditions would protect the victim from the accused. ${ }^{106}$

Historically, the purpose of bail has been to ensure that the defendant returns to court for the hearing of their matter and to ensure the integrity of the trial. ${ }^{107}$ Elsewhere, David Brown has identified that certain approaches, such as identifying categories of offence and types of prior convictions as grounds for refusing bail, shift bail to a crime prevention strategy. ${ }^{108}$ He points out that categories of offence and prior convictions operate as markers of risk in a range of ways including:

[First] the actual risk of absconding, interfering with witnesses or evidence, or reoffending/threatening community safety; second the risk to broad notions of community fears and anxieties; and third the political risk to governments of serious offences committed whilst on bail. ${ }^{109}$

102 ALRC/NSWLRC Report, above n 11, [10.24].

103 Ibid, [10.33].

104 See Bail Act 1985 (SA) s 10A; Bail Act 1977 (Vic) s 4(4)(ba).

105 ALRC/NSWLRC Report, above n 11, [10.19].

106 See Re Application for Bail - P I [2014] VSC 64 at [64] (Hollingworth J); Taylor $v$ Western Australia [2014] WASC 292 at [34] (Hall J); Held $v$ The Queen [2012] VSC 648 at [25] (Curtain J).

107 See David Brown, 'Looking Behind the Increase in Custodial Remand Populations' (2013) 2 (2) International Journal for Crime Justice and Social Democracy 80.

108 Ibid, 85.

109 Ibid. 
While Brown observes that the first risk can be seen as focussed on the offender, he notes that 'the elaborate legislative schema of presumptions based on offence type serves to deflect that focus onto the accused's membership of pre-set, legislatively defined categories or populations'. ${ }^{110}$ He argues that the second and third risks cannot be legitimately considered by courts or police but nevertheless they contribute to more 'risk averse and pre-emptive decision-making' ${ }^{111}$ Brown's concern in this analysis is that approaches such as this change the conception of bail and contribute to an increasing remand (and imprisoned) population. Bail regimes already require that decision-makers consider unacceptable risk and the protection of victims in coming to their determination. At this stage there is no evidence that changes to the presumption that we have outlined above have had an impact on reducing domestic violence crime and increased victim safety.

\section{Bail Conditions}

In many cases, the police or court is satisfied that the imposition of certain bail conditions will ensure that the accused does not pose an unacceptable risk to the safety of the victim. Bail conditions can mirror the conditions of a domestic violence protection order, or require compliance with protection order conditions with the consequence that a breach of the protection order also constitutes a breach of bail. ${ }^{112}$ There is some evidence that inconsistencies between bail conditions and protection order conditions arise from time to time. ${ }^{113}$ It is important that conditions do not conflict; any conflict in conditions could be raised by a defendant to justify their breach. The ALRC/NSWLRC Report recommended the introduction of a national protection order database that can be accessed by the police and courts when making bail decisions. ${ }^{114}$ The ALRC/NSWLRC Report noted that although inconsistencies can often be avoided if bail conditions require the accused to comply with existing protection order conditions, this simple formula should not necessarily be adopted in all cases. ${ }^{115}$ It has been suggested that bail conditions provide greater protection since they cannot be withdrawn by the victim. ${ }^{116}$ However, it has also been suggested that police respond more readily to breaches of protection orders compared to breaches of bail. ${ }^{117}$ The ALRC/NSWLRC, along with the WALRC, recommended that legislation should provide that on granting bail, judges should be required to consider whether to impose

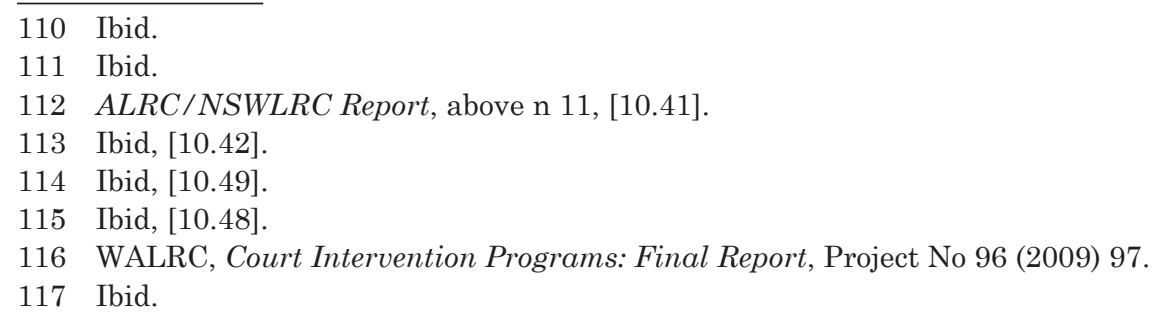


protective bail conditions, issue or vary a protection order, or both. ${ }^{118}$ This position is already reflected in prosecutorial guidelines in several States that recommend that when dealing with bail, prosecutors should also apply for a protection order where none is in place or for changes to the conditions of an existing protection order if the prosecutor is concerned for the safety of the victim. ${ }^{119}$ While this is important, in some cases it will be less onerous for the prosecutor to resist bail or suggest appropriate bail conditions than to apply for a domestic violence protection order. As Neilson J stated:

Before [a domestic violence protection order] can be made, a person ... must have "reasonable grounds to fear", and also in fact fears the commission of violence against him or her, or intimidation of that person, sufficient in the court's view to warrant the making of such an order. To obtain an order appears to me to be a more onerous exercise than imposing bail conditions. The granting of bail is discretionary. ${ }^{120}$

There are two types of bail conditions that are often imposed in family violence matters: exclusion conditions and perpetrator program conditions. These are discussed below.

\section{A Exclusion Conditions}

Frequently, in family violence matters, the police or court will grant bail and impose what are referred to as 'protective bail conditions'. ${ }^{121}$ One such condition is an exclusion condition which prohibits the accused from remaining at or entering the family home, or approaching within a certain distance of the family home.

However, exclusion conditions are problematic when the accused has no alternative accommodation. The ALRC/NSWLRC Report highlighted the courts' reluctance to impose exclusion conditions when issuing protection orders because of their potential to cause significant hardship ultimately homelessness - to the accused. ${ }^{122}$ The ALRC/NSWLRC argued for an integrated response where excluded persons are helped to find

118 ALRC/NSWLRC Report, above n 11, 425 (Recommendation 10-2); WALRC, above n 116, 6 (Recommendation 28).

119 Office of the Director of Public Prosecutions (NSW), Prosecution Guidelines (at 1 June 2007) appendix E, cl 3.2; Office of the Director of Public Prosecutions (Qld), Director's Guidelines (at 1 August 2014) guideline 25(i)(d).

120 Tilse $v$ New South Wales [2013] NSWDC 265, [130] (Neilson J).

121 See, for example, WALRC, Enhancing Family and Domestic Violence Laws, above n 13,134 .

122 ALRC/NSWLRC Report, above n 11, [11.165]; to address this concern, the ALRC/NSWLRC recommended government funding for emergency housing, see [11.226]; it also indicated that exclusion conditions are more effective when the accused is helped to find alternative accommodation because the accused is less likely to return to the family home or be invited back by a sympathetic victim, see [11.197]. See also Rachael Field, Belinda Carpenter and Susan Currie, 'Issues in the Making of Ouster Orders Under the Domestic Violence (Family Protection) Act 1989 (Qld)' in John Dewar and Stephen Parker (eds), Family Law Processes, Practices and Pressures (Hart Publishing, 2003) 99. 
accommodation. This response can be achieved through police training and the establishment of collaborative relationships between police and support services, rather than by imposing a legislative duty on the police to take reasonable steps to secure accommodation. ${ }^{123}$

In its 2007 review of bail, the Victorian Law Reform Commission (VLRC) questioned whether some bail conditions were being used for punishment rather than assistance, arguing that conditions imposed were often onerous, both in nature and in the number imposed, sometimes setting accused persons up to fail. ${ }^{124}$ The VLRC was particularly concerned about blanket restrictions on travel by public transport and broad geographic exclusion zones. ${ }^{125}$ Since breach of bail conditions is a criminal offence in most jurisdictions, ${ }^{126}$ overly onerous conditions can increase the risk of breach. Breach of bail conditions may lead to remand, which could have been avoided if more appropriate conditions were initially imposed. ${ }^{127}$ Generally bail legislation stipulates that that protective bail conditions should be no more onerous than necessary. ${ }^{128}$

\section{B Perpetrator Programs}

Over the past two decades, there has been a trend towards early intervention with the development of perpetrator programs based on a therapeutic justice model. ${ }^{129}$ In Victoria, bail conditions that require accused persons to access support services, treatment or rehabilitation are an established feature of the bail system. ${ }^{130}$ In the Australian Capital Territory, some family violence offenders are found suitable for intervention programs such as the Family Violence Self-Change (FVSC) Program, which is a program designed to change harmful behaviours through cognitive restructuring. ${ }^{131}$ In 2006-2007, five out of the 65 FVSC participants participated in the program as part of their bail conditions. In 2007-2008, this figure was 12 out of $111 . .^{132}$

123 ALRC/NSWLRC Report, above n 11, [11.229].

124 VLRC, above n 13, 123. See also, generally, Brown, above n 107, and Arie Freiberg and Neil Morgan, 'Between Bail and Sentence: The Conflation of Dispositional Options' (2004) 15(3) Current Issues in Criminal Justice 220.

125 VLRC, above n 13, 62. For an example of a case where several onerous exclusion conditions were imposed, see Re Anderson [2011] ACTSC 121 (Refshauge J).

126 See Bail Act 1980 (Qld) s 29; Bail Act 1985 (SA) s 17(1); Bail Act 1994 (Tas) s 9; Bail Act 1977 (Vic) s 30A; Bail Act 1982 (WA) s 51(2a); Bail Act 1982 (NT) s 37B.

127 VLRC, above n 13, 62.

128 Ibid, 124 (Recommendation 95). See Bail Act 1980 (Qld) s 11(1), (5); Bail Act 1977 (Vic) s 5(4); Bail Amendment Act 2010 (Vic) s 8.

129 Julie Stewart, 'Specialist Domestic Violence Courts: What We Know Now - How Far Have Australian Jurisdictions Progressed? (Topic Paper 20, Australian Domestic and Family Violence Clearinghouse, 2010) 1.

130 VLRC, above n 7, 121.

131 Tracy Cussen and Mathew Lyneham, 'ACT Family Intervention Program Review' (Technical and Background Paper No 52, Australian Institute of Criminology, 2012) 10.

132 Ibid, 64. These low figures suggest that the program is rarely imposed at the bail stage. 
In South Australia, family violence offences can be diverted from a general court list to the Family Violence Court. The Family Violence Court Magistrate will consider adjourning the matter for a period of four weeks with supervised bail on the condition that the defendant attends a treatment program assessment. In order to be assessed as suitable, the defendant must acknowledge their past abuse, recognise that this behaviour is problematic, and show a desire to address their behaviour. ${ }^{133}$ If the defendant is found suitable, bail is extended for approximately 24 weeks to allow the accused to complete the program. ${ }^{134}$ There is a similar scheme in place in Western Australia. ${ }^{135}$ However, the present eligibility criteria require, among other things, that the offender must enter a plea of guilty to a family violence related offence. ${ }^{136}$ In these cases, as guilt is admitted, bail continues to operate to ensure the person's appearance at court for sentencing, and conditions can be applied to ensure the safety of others, but it also gives the offender the opportunity to address the issues underlying the offending behaviour before the court deciding on the appropriate sentence. While there is a danger that a post-plea eligibility criterion may pressure defendants to plead guilty to secure bail, pre-plea participation in programs with limited capacity may redirect placements to less motivated offenders. This may have negative implications for compliance and completion rates. ${ }^{137}$

Submissions to the VLRC's review of bail expressed concern about defendants who are presumed innocent being mandatorily required to attend rehabilitation programs and the need to ensure the use of such conditions for purposes that legitimately relate to bail. ${ }^{138}$ The VLRC recognised the risk of bail conditions being conflated with penalty and argued that the distinction between bail and sentence must be maintained. The VLRC found that it is more appropriate to impose perpetrator program conditions on accused persons in the sentencing process or after a deferral of sentence, when a guilty plea has been entered. ${ }^{139}$ In contrast, the WALRC recommended that participation in court intervention programs should be allowed before a plea of guilty or full admission of the facts so long as the person has accepted responsibility for the offending behaviour. ${ }^{140}$ This

133 Legal Service Commission of South Australia, Family Violence Court (2012) <www.lsc.sa.gov.au/dsh/ch04s09.php>.

134 Department for Correctional Services (SA), Abuse Prevention Program (2010) $<$ http://www.courts.sa.gov.au/OurCourts/MagistratesCourt/Intervention Programs/Pages/Abuse-Prevention-Program-and-Family-Violence-Courts.aspx>; Court Administration of South Australia, Court Intervention Programs (2012) $<$ www.courts.sa.gov.au/OurCourts/MagistratesCourt/InterventionPrograms/ Pages/default.aspx $>$.

135 WALRC, Court Intervention Programs: Consultation Paper, Project No 96 (June 2008) 129-139; see also Bail Act 1982 (WA) Sch 1 Pt D cl 2(2b).

136 WALRC, above n 116, 94.

137 See, generally, Stewart, above n 129, 7.

138 VLRC, above n 7, 121.

139 Ibid, 122.

140 WALRC, above n 116, 94. 
approach allows genuinely remorseful offenders to participate as soon as possible in a program, even where there is some dispute about the statement of material facts. ${ }^{141}$ Research about the success of perpetrator programs has produced mixed results. ${ }^{142}$ However, some research suggests that the earlier the person attends a perpetrator program, the more likely they will cease offending. ${ }^{143}$ Recent findings from the Project Mirabal study conducted in the United Kingdom showed a number of positive results where perpetrators took part in a perpetrator program including large decreases in violence and some decreases in abuse. ${ }^{144}$ In earlier studies Gondolf found that men were less likely to reoffend when they were placed in perpetrator programs within weeks of arrest as opposed to waiting for conviction, which may be several months post-arrest. ${ }^{145}$ It seems important that opportunities to attend a perpetrator program should be available as early as possible and thus bail may be an appropriate point in time to encourage and support this engagement as a condition of bail. However, increased requirements such as program attendance should be carefully considered given that bail orders are made in a context where there is not yet a finding of guilt. In some cases such conditions may be considered to be too onerous and more like a sentence.

\section{Conclusion}

As is shown here, there are a number of different approaches to bail in domestic violence cases in Australia. Most controversial is the introduction of a presumption against bail. In 2010, the ALRC/NSWLRC considered submissions about whether provisions containing a neutral presumption or presumption against bail, in family violence cases, strike the right balance between ensuring the safety and wellbeing of victims and safeguarding the rights of the accused. It concluded that victim safety is not best secured by a presumption against bail, which might serve as a disincentive to victims to report family violence crimes. Victims may not want the accused to be incarcerated, and depending on the type of breach and history of violence, it may be in the best interests of the family for the accused to remain in employment. ${ }^{146}$ Some have also expressed concerns that presumptions against bail disproportionally affect Indigenous and

141 Ibid.

142 Thea Brown and Ralph Hampson, An Evaluation of Interventions with Domestic Violence Perpetrators (Monash University Printing, 2009).

143 See Edward W Gondolf, 'Evaluating Batterer Programs: A Different Task Showing Some Effects and Implications' (2004) 9 Aggression and Violent Behaviour 605, 609.

144 Liz Kelly and Nicole Westmarland, Domestic Violence Perpetrator Programmes: Steps Towards Change. Project Mirabal Final Report (London Metropolitan University and Durham University, 2015) 22.

145 Gondolf, above n 143. See also Heather Douglas, 'Not a Crime Like Any Other: Sentencing Breaches of Domestic Violence Protection Orders' (2007) 31 Criminal Law Journal 220, 226.

146 ALRC/NSWLRC Report, above n 11, 419. 
unrepresented offenders, ${ }^{147}$ although it is not clear whether presumptions against bail systematically disadvantage particular offenders. ${ }^{148}$ The ALRC/NSWLRC recommended maintaining a general presumption in favour of bail which can be displaced in specific circumstances, such as where the accused has been violent against the victim in the past. ${ }^{149} \mathrm{It}$ did not elaborate on whether previous violence would require evidence of previous convictions or if victim testimony would be sufficient to displace the presumption.

In its 2007 report, the VLRC found that the presumption against bail is problematic in the family violence context because of the untested nature of the alleged behaviour in circumstances where the victim's testimony is usually the main source of evidence. ${ }^{150}$ The strength of the prosecution case is a factor the courts routinely take into account when determining whether to grant bail. ${ }^{151}$ While evidence of the victim's physical injuries or corroborating witness accounts may strengthen the prosecution case, ${ }^{152}$ these other pieces of evidence may be unavailable in many domestic violence prosecutions. Thus the strength of the prosecution case may hinge on the victim's claims. However, assessing the credibility of the victim at the bail stage is generally inappropriate, in a part because it requires the victim to retell her story risking further opportunity for secondary victimisation, ${ }^{153}$ and because it is not the role of the court in a bail hearing to assess whether the victim's account would be perceived as honest and reliable by a jury. ${ }^{154}$

A further concern about the legislative changes that have occurred in relation to the presumption of bail in family violence cases is that they apply only in limited types of family violence cases and contexts (for example, for particular charges and histories). Such approaches may establish a type of family violence hierarchy suggesting some cases are of less concern than others. Judicial officers need to weigh the competing concerns of rights to liberty and victim protection extremely carefully in all cases involving family violence.

Protective bail conditions should, of course, be no more onerous than necessary to ensure the protection of members of the community and to minimise the defendant's risk of breaching bail. Appropriate bail support

147 See, for example, Pheeney, above n 36; Olsen v Tasmania [2005] TASSC 40 (13 May 2005) (Underwood CJ); Re S [2005] TASSC 89 (19 September 2005) (Slicer J).

148 Snowball, Roth and Weatherburn, above $\mathrm{n} 40$, found that the Indigenous status of defendants was a risk factor for bail refusal. However, the authors noted that the study probably failed to control for several important bail considerations, such as a defendant's community ties and previous failings to appear in court.

149 ALRC/NSWLRC Report, above n 11, 420.

150 VLRC Report, above n 7, 38.

151 See, for example, Held $v$ The Queen [2012] VSC 648 (4 December 2012).

152 Re Application for Bail - P I [2014] VSC 64.

153 J Herman, 'Justice from the Victim's Perspective' (2005) 11(5) Violence Against Women 571.

$154 R$ v Christodoulou [2005] NSWSC 1362 (15 December 2005) at [16]. 
initiatives that focus on assisting the accused to adhere to their bail conditions are crucial in addressing this aim. For example, there should be greater consideration of how emergency housing can be funded to help the accused find alternative accommodation. There is increasing evidence that perpetrator programs help to decrease physical violence and abuse in domestic violence cases. ${ }^{155}$ We suggest that perpetrator programs should be available to defendants who plead guilty, agree on the facts alleged, or indicate an intention to plead guilty where there is some minor dispute about the statement of material facts. It is observed that it may be inappropriate to impose mandatory programs on unwilling defendants as a condition of bail, as this approach appears to increase the risk of the accused breaching a bail condition and consequently facing a custodial sentence. ${ }^{156}$

Bail is a core component of the criminal justice response to family violence. At present, there is insufficient research into the effectiveness of the various bail responses discussed in this article. Further research is needed to determine which approach best balances the continuing safety of victims of family violence with the rights of the accused. In cases concerning family violence, the safety of women and children should always be a key consideration in the bail response. Retaining a presumption in favour of bail in cases of family violence offences is not inconsistent with this aim. Any other approach may disproportionately disadvantage Indigenous and unrepresented offenders who may find it difficult to present evidence in support of an application for bail. Where bail is granted in domestic violence cases, particular attention should be paid to crafting conditions that are appropriate to the defendant and the defendant's history of violence towards the alleged victim, while ensuring consistency with any protection orders.

155 Kelly and Westmarland, above n 144.

156 See, generally, Kelly Richards and Lauren Renshaw, 'Bail and Remand for Young People in Australia: A National Research Project' (Research and Public Policy Series No 125, Australian Institute of Criminology, 2013). 